\title{
Implementation of Regional Regulation Number 1 of 2014 Regarding Regional Spatial Planning of North Mamuju Regency-based on Sustainable Development
}

\author{
Agus Ambo Jiwa ${ }^{1}$, Abdul Hakim $^{2}$, Endah Setyowati ${ }^{3}$, Andi Tamsil ${ }^{4}$ \\ \{pdi12019pasca@gmail.com ${ }^{1}$ \} \\ Universitas Brawijaya, Indonesia ${ }^{1,2,3,4}$
}

\begin{abstract}
Pasangkayu or North Mamuju Regency is a result of the division of Mamuju Regency, West Sulawesi that implements the sustainable development. The government of the Pasangkayu Regency issued Regional Regulation Number 1 of 2014 regarding Spatial Planning to deal with the geographical conditions (rural), socio-cultural development which is quite wide and very dynamic. The objectives of this research are to identify the supporting factors and inhibitors, and to describe and analyze the implementation of Pasangkayu Regency Regulation Number 1 of 2014. The Edward III model approach was used referring to the condition of the Pasangkayu Regency. Data collection was carried out by observation, interview, documentation, and focus group discussion (FGD) techniques. Data analysis was performed using the Miles and Huberman model, which consisted of 4 components: data collection, data condensation, data display, and conclusions or interpretations. The implementation of the regional spatial planning policy in the Pasangkayu Regency is characterized by supporting and inhibiting factors from internal and external agencies/institutions. These two factors have an impact on the success of the regional spatial planning policy. The main force in implementing the spatial planning policy is the most dominant communication variable in the policy implementor. In addition, the disaster factor is also an important factor in supporting the implementation of the regional spatial planning regulation in the Pasangkayu Regency. In connection with the map of potential disasters, the potential for exposed populations and the potential for disaster losses, a comprehensive disaster mitigation study needs to be carried out in the future.
\end{abstract}

Keywords: Pasangkayu Regency, Regional Regulation, Spatial Planning, Sustainable Development.

\section{Introduction}

Indonesia as one of the countries that have agreed on the implementation of sustainable development goals (SDGs) is committed through various activities and has taken strategic steps to succeed in the implementation of SDGs [1]. The objectives of sustainable development are to improve the prosperity of the community and to fulfill the needs and aspirations of humans [2]. According to Sutamihardja [3], the purpose of sustainable development is to create the benefit equality of intergenerational development outcomes (Intergeneration Equity), to preserve the disruption of natural resource conservation (Safeguarding), sustainable economic growth between generations, people's welfare, long-term natural resource management, and the quality of human life among generations according to their habitat. These conditions are 
supported by a number of basic reasons such as moral, ecological, and economic [4], thus preventing environmental degradation [5]. The sustainable development concept is considered the most appropriate way to be implemented in Indonesia which has abundant natural resources

Pasangkayu or North Mamuju Regency is a result of the division of Mamuju Regency, West Sulawesi, which was legalized by UU no. 7 of 2003. Pasangkayu Regency with Pasangkayu capital city has 12 districts according to Pasangkayu Regional Regulation Number 9 of 2007. The government of the Pasangkayu Regency also issued Regional Regulation Number 1 of 2014 regarding Spatial Planning for the North Mamuju Regency in 2014-2034 to deal with the geographical conditions (rural), socio-cultural development which is quite wide and very dynamic. Sustainable development is implemented at a lower level by formulating regional spatial planning in RTRW. The implementation is supported by Regional Regulation Number 8 of 2016 regarding the Regional Medium-Term Development Plan (RPJMD) of the North Mamuju Regency in 2016-2021. The selection of RTRW as an object of sustainable development because it has strategic value and has the potential as the guideline for spatial planning, also as a reference for the whole development implementation that becomes a manifestation of public policy [3][6][7][8]. The complexity of the regulation implementation contained in Regional Regulation Number 1 of 2014, which used as a reference and guideline for the implementation of sustainable development in the Pasangkayu Regency.

The aspects of sustainable development contained in Spatial Planning of Pasangkayu Regency consists of improving the service in the social, economic, transportation, energy, communications, protection and development of water resources, protected functioning areas, development of agricultural centers, fisheries, environmentally friendly mining, tourism, and enhancing the functions of defense and security zone. During the implementation period, these aspects have been well implemented such as the improvement, development, and rehabilitation of protected function areas, and the development of environmentally friendly mining activities. However, in several other aspects, further improvements in their implementation need to be made, such as the improvement and development of transportation networks, energy, telecommunications, water resources, thus causing government problems that need to be resolved by the Pasangkayu Regency government.

The objectives of this research are to identify the supporting factors and inhibitors, and to describe and analyze the implementation of Pasangkayu Regency Regulation Number 1 of 2014. The Edward III (1980) model approach was used referring to the condition of the Pasangkayu Regency. The model is included in a top-down model or a direct model and direct impact on implementation with 4 model variables: communication, resources, disposition, and bureaucratic structure. This model formula is considered capable of being a theoretical tool for assessing the successful implementation of spatial planning policies in Pasangkayu Regency, West Sulawesi.

\section{Material and Method}

\subsection{Area Study}

The research was conducted in Pasangkayu District, Pasangkayu Regency, West Sulawesi (Fig. 1) between November 2018-May 2019. The qualitative data were analyzed using the Edward III model and involving the informant as the resource of the study. The informant was determined with several considered criteria: a) Apparatus at the Regional Planning, Research, 
and Development Agency of Pasangkayu Regency; b) Apparatus at the Environmental Service Department of Pasangkayu Regency; c) Apparatus at the Public Works and Spatial Planning Department of Pasangkayu Regency; d) Apparatus in the District Office of North Mamuju, Pasangkayu Regency; e) Administrator of Environmental Organization in Pasangkayu Regency; and f) Community in the Pasangkayu District, Pasangkayu Regency.

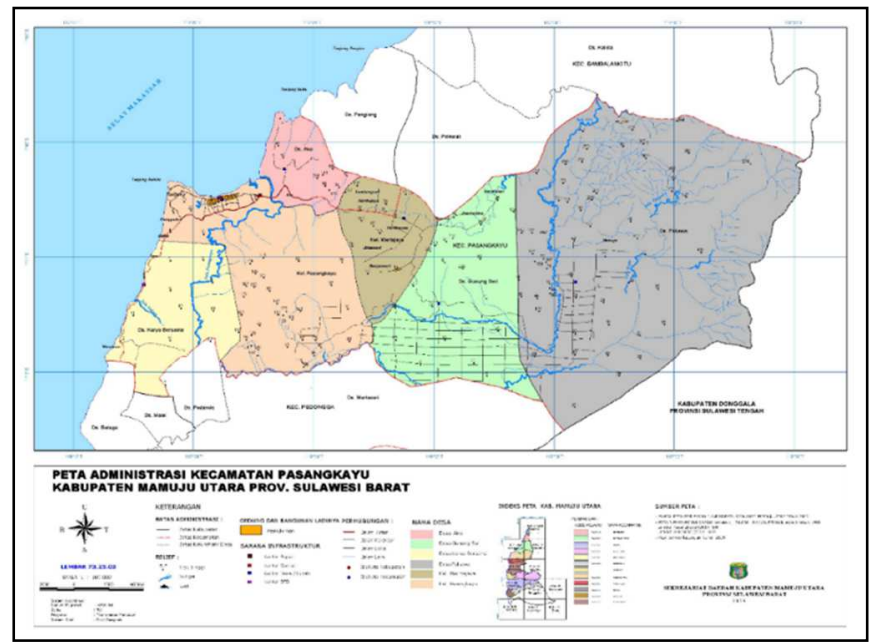

Fig. 1. Area study in the Capital City of Pasangkayu Regency is marked with gray color.

\subsection{Data Collection}

Interview data collection was conducted at the meetings that discussed the spatial planning, development activities in Pasangkayu Regency, community meetings related to RTRW, and local physical environment.

The source of document data such as RPJMD document, Regional Strategic Plan (Renstra) document, North Mamuju Regency book administration, and regulations regarding spatial planning, and reports related to spatial planning. Data collection was carried out by observation, interview, documentation, and focus group discussion (FGD) techniques. Data analysis was performed using the Miles and Huberman model [9], which consisted of 4 components: data collection, data condensation, data display, and conclusions or interpretations (Figure 2).

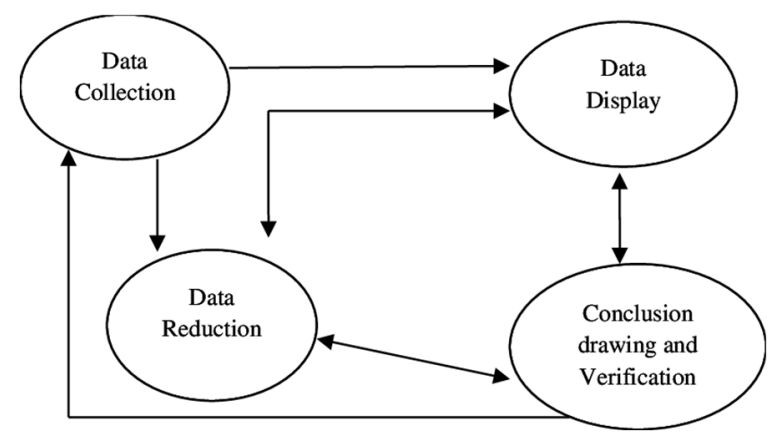

Fig. 2. The Components of Milles \& Huberman Interactive Model Data Analysis. 


\section{Result and Discussion}

Implementation of Regional Regulation policy regarding Spatial Planning (RTRW) by the government and non-governmental institutions is influenced by both supporting and inhibiting factors. The supporting factors emerge from the internal institutions (government) and outside of policy implementation institutions. Some factors found in the implementation of this policy are about human resource support which includes:

a) The ability of the main implementor (Regional Head) communication in executing this regulation both internally and externally;

b) The implementer has a proper and comprehensive understanding;

c) The existence of positive attitudes and tendencies of the regulation's implementer;

d) Legislative board support in supervision.

Referring to the four variables from Edward III (1980), the main force in implementing the spatial planning policy is the most dominant communication variable in the policy implementor. However, the support of communication skills must be balanced between the implementor at the level of the Head of Service, Head of Division, Head of Section, and the implementor at the lower level hence the implementation of the policy is more effective and efficient in the future. Another aspect that supports the implementation is the socialization and supervision by the People's Regional Representative Council on the implementation of this policy. This aspect is certainly considered as one of the factors supporting the implementation of the spatial planning policy in the bureaucratic structure variable category, especially in the external aspect. Factors inhibiting the implementation of this policy include:

a) Lack of community understanding related to sustainable development;

b) Lack of facilities/offices that are comfortable in providing services to the community;

c) Limited funding factors for the implementation of all policies in spatial planning (RTRW).

The level of community compliance in implementing the regional spatial planning policy in the Pasangkayu Regency still needs further development in the future. The results of the study note that this is caused by most of the people both individually and groups have limited understanding about the urgency of the regional spatial planning and whole sustainable development which represents the limited level of education and most of them did not have legality (licensing) before carrying out development. Curry [5] explain that the development of community participation and compliance begins with the development of personal interests, once they accustomed to the planning system, they will begin to be interested in the community benefits that can be generated by the system and gradually compliance and participation are formed. Thus, intensive communication with the community to build community benefits and understanding related to urgency of regional spatial planning and sustainable development must be carried out in the context of the maximum realization of the implementation of regional spatial planning policy.

The dimensions that influence the supporting and inhibiting factors in policy implementation are disaster related to potential and mitigation. Pasangkayu Regency is one of the regions that has disaster potential. Potential disasters can be determined based on geographical, climatological and demographic conditions. The condition of Pasangkayu Regency in the middle of the Palu-Koro Fault Zone (ZSPK) is one of the triggers for potential geological disasters such as the earthquake and tsunami. In addition, climatological conditions, namely rainfall, are one of the emergences causes of hydrometeorological potential disasters such as floods, extreme waves, land and forest fires, drought, and extreme weather. Based on these conditions, several potential disasters that have occurred in Pasangkayu Regency were floods, 
landslides, extreme weather, extreme waves, abrasion, flash floods, and earthquakes. Meanwhile, other potential disasters that have never occurred include the tsunami, drought, and forest and land fires. These potential disasters are considered a major threat to the population in Pasangkayu Regency.

Floods that occurred in Pasangkayu Regency were caused by natural factors and human factors. Floods are naturally caused by high rainfall so that river bodies are unable to accommodate surface water flow from the hills and cause water to overflow into the residents' housing. As a human factor, land use that is incompatible with ecological functions also indirectly increases the potential for flood hazards. This condition occurs not only in the downstream area but also in the upstream area. Most of the subdistrict areas in the Pasangkayu Regency have low flood hazard classes, only Dapurang District and Sarudu District which have medium hazard classes. Both districts need to get more attention so as not to cause greater losses. Efforts to deal with these problems can be done by applying absorption wells and bio pores, and river restoration. One of the prevention efforts can be carried out by developing a system of management and monitoring of the watershed upstream areas on the Lariang River, Selo Pebatua River, and Pasangkayu River.

Forest and land fire disasters usually occur in the long dry season, causing flammable conditions. Fires also occur due to human activity, for example, throwing cigarette butts that are still burning carelessly and burning forests for land clearing. The distribution of forest and land potential disaster areas is calculated based on parameters of land cover, rainfall and soil type. From the results of the study, Pasangkayu District has a high level of risk for forest and land fires, especially in the Pasangkayu sub-district.

Drought is a result of the clean water availability that is far below the requirement for life, agriculture, economic activities, and the environment. The drought examined in the Pasangkayu Regency Disaster Risk Study was a meteorological drought associated with below normal rainfall levels in one season. The meteorological drought study is the first indication of a drought. The method used in the study of drought hazards was the Standardized Precipitation Index (SPI) which used rainfall data as the main parameter. From these parameters, it could be determined the area and the class of drought hazards in the Pasangkayu Regency. Drought occurred almost evenly in all districts of the Pasangkayu Regency. This happened because there was no rain fell for more than four months hence the water supply needed in several ponds and rice fields was reduced.

Landslides in Pasangkayu Regency were caused by several factors such as morphological conditions, rock or soil type, and triggering factors, namely high-intensity rainfall. The morphological condition of the Pasangkayu Regency is partly in the form of highlands and hills, and has steep hill topography, especially in the north. This results in a greater potential for landslides to occur in the area, especially in the Kitchenang District and Bulu Taba District that have slopes of more than 30 percent.

Pasangkayu Regency is included in the tsunami-prone zone, especially in Sarjo Sub-district, Bambaira Sub-district, Bambalamotu Sub-district, Pasangkayu Sub-district, Pedongga Subdistrict, Tikke Raya Sub-district, Lariang Sub-district, Baras Sub-district, Sarudu Sub-district, and Dapurang Sub-district. This was caused by several faults under the waters of the Pasangkayu Regency. The closest active faults are the Palu Koro Fault and the Makassar Strait Fault. One of the solutions to reduce the risk level of tsunami disaster is to create a structural mitigation design for tsunami wave-retaining structures such as plants and/or wave-retaining structures reinforced by regional regulations. In connection with the map of potential disasters, the potential for exposed populations and the potential for disaster losses, a comprehensive disaster mitigation study needs to be carried out in the future. 


\section{Conclusion}

The implementation of the regional spatial planning policy in the Pasangkayu Regency is characterized by supporting and inhibiting factors from internal and external agencies/institutions. These two factors definitely have an impact on the success of the regional spatial planning policy. In addition, the disaster factor is also an important factor in supporting the implementation of the regional spatial planning regulation in the Pasangkayu Regency. In connection with the map of potential disasters, the potential for exposed populations and the potential for disaster losses, a comprehensive disaster mitigation study needs to be carried out in the future.

\subsection{Acknowledgment}

Thank you to Pasangkayu Regency for supporting this research and the entire academic community of the Doctor of Environmental Science, Postgraduate School, Brawijaya University, Malang.

\section{References}

[1] BPS, Potret Awal Tujuan Pembangunan Berkelanjutan (Sustainable Development Goals) di Indonesia. Jakarta: Badan Pusat Statistik, 2016.

[2] I. F. Ulfah, A. Setiawan, and A. Rahmawati, "Pembangunan Desa Berbasis Potensi Lokal Agrowisata di desa Bumiaji, Kota Batu, Jawa Timur," Polit. Indones. Indones. Polit. Sci. Rev., vol. 2, no. 1, pp. 46-64, 2017.

[3] Sutamihardja, Perubahan Lingkungan Global: Program Studi Pengelolaan Sumber Daya Alam dan Lingkungan. Sekolah Pascasarjana: IPB, 2004.

[4] A. Fauzi, Ekonomi sumber daya alam dan lingkungan: Teori dan aplikasi. Gramedia Pustaka Utama, 2004.

[5] N. Curry, "Community participation in spatial planning: exploring relationships between professional and lay stakeholders," Local Gov. Stud., vol. 38, no. 3, pp. 345-366, 2012.

[6] G. C. Edward III, Implementing Public Policy. Washington: Congressional Quarterly Press, 1980.

[7] H. Pasolong, "Teori Administrasi Publik, Alfabeta." Bandung, 2008.

[8] S. Wibawa, "Politik Perumusan Kebijakan Publik," Yogyakarta Graha Ilmu, 2011.

[9] M. B. Miles and A. M. Huberman, “Analisis data kualitatif.” Jakarta: UI press, 1992. 